\title{
CALCULATION OF SHORT OPTICAL PULSES BY USING TWO SECTIONS PASSIVE Q- SWITCHING DIODE LASER
}

\author{
Fariborz Parandin, Mohammad Mehdi Karkhanehchi, Reza Hemmati, Naser Mahtabi
}

Original scientific paper

In order to attain the optical pulses with high frequency, the pulse-width must be very short. In practical systems, passive Q-switching is mainly regarded as one of the main methods to generate the short optical pulses. In passive Q-switching method, the optical pulses are generated by using laser parameters and therefore, the external electrical or optical modulators are not required to generate the optical pulses. This issue is regarded as the advantage of the passive Q-switching method compared to the other methods. In this paper, a model for two-section passive Q-switching diode laser is proposed. In the suggested method, the changing rates of the carriers are obtained in two regions by solving the equations. As well, by applying this mechanism, the pulse generation is described. Furthermore, the pulse width is achieved and it is demonstrated that the pulse width depends on the physical parameters of the laser.

Keywords: carriers changing rate; diode laser; mathematical modelling; short optical pulses; two-section passive Q-switching

Proračun kratkih optičkih impulsa pomoću pasivnog diodnog lasera Q-uključivanja s dva dijela

Izvorni znanstveni članak

Kako bi se dobili optički impulsi visoke frekvencije, širina impulsa mora biti vrlo kratka. U praktičnim sustavima pasivno Q-uključivanje se smatra jednom od glavnih metoda za generiranje kratkih optičkih impulsa. U metodi pasivnog Q-uključivanja optički se impulsi generiraju parametrima lasera i stoga eksterni električni ili optički modulatori nisu potrebni za generiranje optičkih impulsa. To se smatra prednošću metode pasivnog Q-uključivanja u usporedbi s drugim metodama. U ovom se radu predlaže pasivni diodni laser Q-uključivanja s dva dijela. U predloženoj se metodi brzina promjene prijenosnika postiže u dva područja rješavanjem jednadžbi. Isto tako, primjenom ovog mehanizma opisuje se generiranje impulsa. Nadalje, postiže se širina impulsa i pokazuje da širina impulsa ovisi o fizikalnim parametrima lasera.

Ključne riječi: brzina promjene prijenosnika; diodni laser; matematičko modeliranje; kratki optički impulsi; pasivno Q-uključivanje s dva dijela

\section{Introduction}

The first successful demonstration of a semiconductor laser took place in 1962. Two years later Lasher proposed a two-section bistable laser consisting of a Fabry-Perot injection laser with two electrically isolated p-contacts. Passive Q-switching diode lasers have two sections: one section, which is longer and forward, biased, is called optical gain, and the other section, which is smaller and reverse biased, is called saturable absorber, which generates optical pulses. In fact, saturable absorber part absorbs the generated photons in gain section until it saturates and then no longer photons are absorbed, then the optical pulses are generated at this time. With photons emission, carriers decrease in gain region and gain value is decreased.

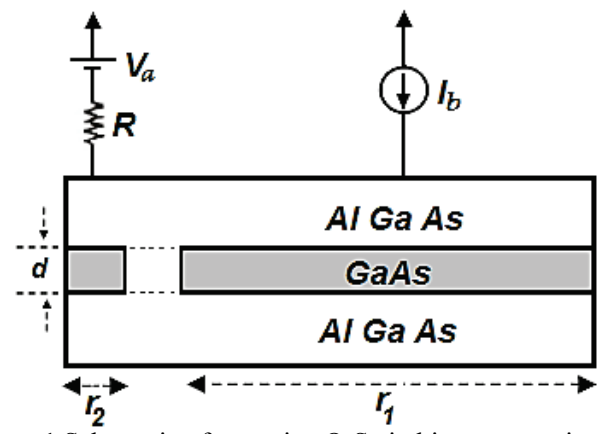

Figure 1 Schematic of a passive Q-Switching two section laser

At the same time, carriers in absorber section are bleached until decreased to saturated values. Nevertheless, because the decreasing losses are much higher than the decreasing gain, the gain value is larger than the losses and optical pulses are generated until gain value is lower than loss value and optical pulses are cut off $[1 \div 4]$. This optical switching is based on the mechanism of controlling the reflectivity of the FabryPerot saturable absorber, while operating at its resonant

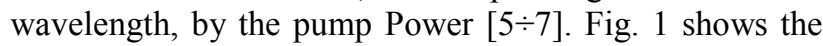
schematic of a passive Q-switching two-section semiconductor laser. In Fig. 1, there are gain and saturable absorber lengths, respectively [10].

\section{Mathematical models and pulse-width calculation}

Mathematical models which can be written for passive Q-switching semiconductor laser, contain three nonlinear differential equations. The equations show the rate changes of carriers in gain and absorber sections and the rate of changes of photons in gain region [9].

$$
\begin{aligned}
& \frac{\mathrm{d} n_{1}}{\mathrm{~d} t}=\frac{J}{e d}-\frac{n_{1}}{\tau_{1}}-v_{g} a_{1}\left(n_{1}-N_{g_{1}}\right) S, \\
& \frac{\mathrm{d} n_{2}}{\mathrm{~d} t}=-\frac{n_{2}}{\tau_{2}}+v_{g} a_{2}\left(N_{g_{2}}-n_{2}\right) S, \\
& \frac{\mathrm{d} S}{\mathrm{~d} t}=\left[\Gamma v_{g} f_{1} a_{1}\left(n_{1}-N_{g_{1}}\right)-\Gamma v_{g} f_{2} a_{2}\left(N_{g_{2}}-n_{2}\right)-\frac{1}{\tau_{p h}}\right] S
\end{aligned}
$$

In above equation, $n_{1}$ and $n_{2}$ show the carrier's density of gain and absorber sections, $S$ indicates the photon density, $\tau_{1}$ and $\tau_{2}$ are the carriers lifetime, $v_{g}$ is the group velocity, $J$ is current density, $d$ is active layer width, and $e$ is electron charge. $N_{g 1}$ and $N_{g 2}$ are the carriers density of gain and absorber in threshold lasing section, respectively. $f_{1}$ and $f_{2}$ are the gain and absorber lengths 
and $\Gamma$ is confinement factor. As well, $a_{1}$ and $a_{2}$ are the differential gain and absorber coefficients and calculated as follows:

$a_{1}=\frac{\partial g}{\partial n_{1}}, a_{2}=\frac{\partial \alpha}{\partial n_{2}}$

where $g$ and $\alpha$ are gain and absorber coefficient. The pulse shape which is considered for optical pulses in solving the equations is:

$S(t)=p \sec h^{2}\left(\frac{t}{\tau}\right)$

where $\tau$ is pulse width and $p$ is pulse amplitude. For solving these equations, we assume that the pulse width is short compared to repetition rate. Also, the laser is lasing in single frequency and the changes of the carriers and photons in all direction are negligible. In the optical pulse generation, losses change very fast. In the initial time of pulse, loss is decreased rapidly and them it will be constant. Therefore, one can obtain from equation (2) the carrier density in absorber section [10]:

$$
n_{2}(t)=\frac{v_{g} a_{2} N_{g 2} S}{v_{g} a_{2} S+\frac{1}{\tau_{2}}}
$$

Also in this range, since many photons are generated in the gain region, one can write the equation (1) as follow:

$\frac{\mathrm{d} n_{1}}{\mathrm{~d} t} \cong-v_{g} a_{1}\left(n_{1}-N_{g 1}\right) S$

One answer for above differential equation is as follows:

$$
n_{1}(t)=N_{g 1}+n_{0} \exp \left\{-v_{g} a_{1} p \tau\left[1+\tan h\left(\frac{t}{\tau}\right)\right]\right\}
$$

where $n_{0}$ is a constant value and can be obtained from the solution of the equations. With substituting equations (5) to (8) in equation (3) one can obtain the pulse width as follows [10]:

$$
\tau=\frac{2 \tau_{p h}}{1+\tau_{p h} v_{g} \Gamma f_{2} a_{2} N_{g_{2}}} \times\left(\frac{\Gamma \tau_{2} v_{g} f_{2} a_{2}^{2} N_{g 2}}{\left(a_{1}-\frac{a_{1}^{2}}{\Gamma \tau_{2} v_{g} f_{2} a_{2}^{2} N_{g_{2}}}\right)}-1\right)
$$

\section{Results and graphs}

By using the relations, which were obtained before, one can obtain the changes of carriers in gain and absorber sections in terms of time, which is shown in Fig. 2 .
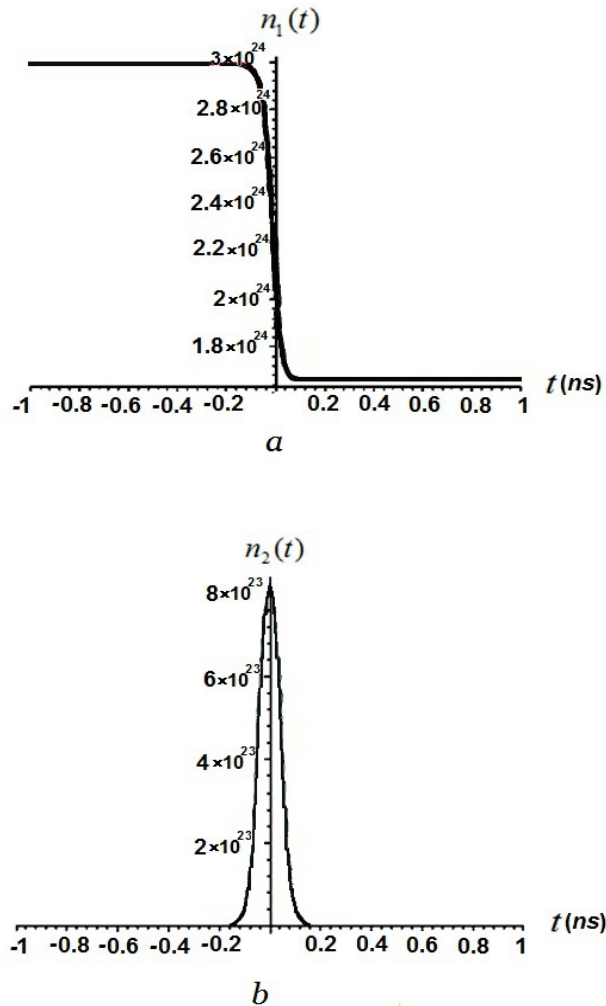

Figure 2 The changes of carriers along time in gain region (a) and absorber region (b)

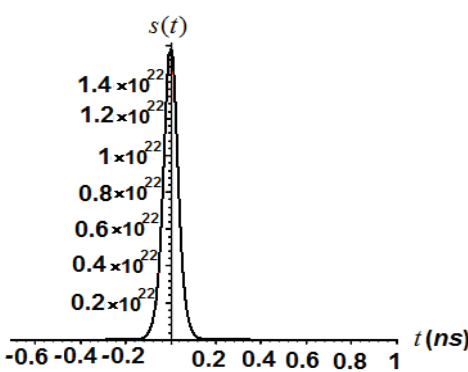

Figure 3 The changes of the photons density in terms of time

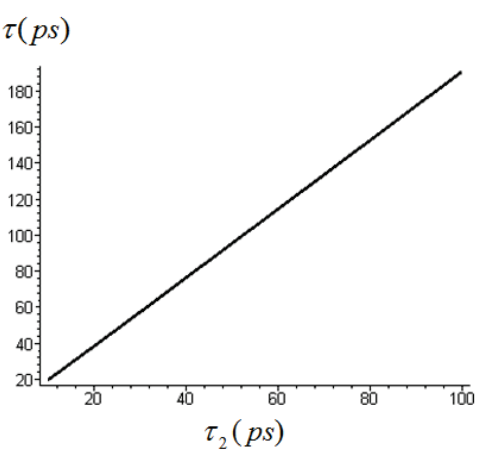

Figure 4 The changes of the pulse width in terms of the carrier's lifetime in absorber section

It is observed in Fig. 2 that from the beginning of the generation of the optical pulse the carrier's density in absorber section is increased and in threshold lasing the carriers are decreased rapidly because so many photons are generated in gain section. The changes of the photons density in terms of time is shown in Fig. 3. 
The optical pulse width in passive Q-switching semiconductor lasers is changed in terms of the carrier's lifetime in absorber section. This change is shown in Fig. 4.
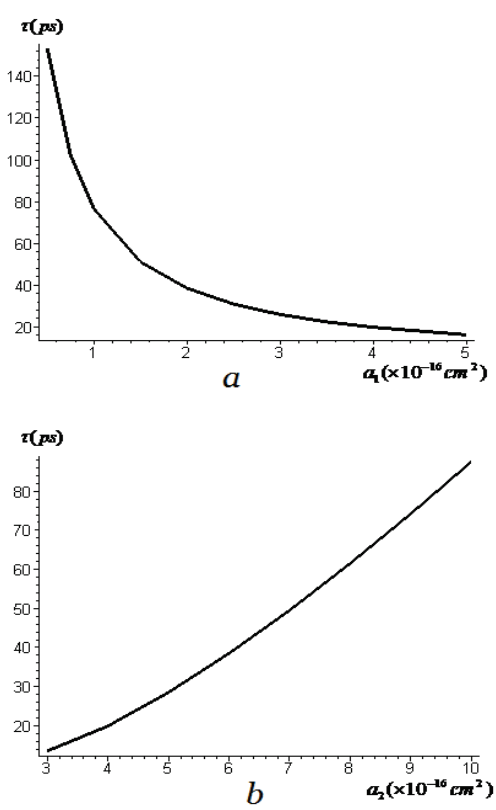

Figure 5 The changes in the pulse width in terms of the differential gain in gain section (a) and the differential gain in absorber section

As stated before, while the optical pulses are emitted, the saturable absorber is saturated and it can no longer absorb the photons from the gain region. Therefore, when the carriers lifetime in saturable absorber is high, the saturable time is also increased and the time to generate pulses and therefore the pulse width is increased. By width changing, the differential gain in the gain and absorber sections and the optical pulse width in the passive Qswitching semiconductor lasers are changed. These changes are shown in Fig. 5.

\section{Conclusions}

This paper addressed a new and optimal mechanism to generate the optical pulse in passive Q-switching diode laser. The passive Q-switching diode laser is mainly considered as one of the most important sources to generate short optical pulses. Furthermore, a mathematical formulation was derived for optical pulsewidth which can be used in further studies. Many issues about pulse-width changing were investigated, e.g. the changes of the pulse-width in terms of carrier's lifetime in absorber section were thoroughly studied and simulated. Moreover, the changes of the pulse-width in terms of the differential gain in two sections of the lasers were completely investigated.

\section{References}

[1] Vasil, P. P. Ultrashort Diode Lasers. Artech house, INC., 1995.

[2] Wu, L.; Dechun, L.; Shengzhi, Z.; Kejian, Y.; Xiangyang, L.; Reng, W.; Ji, L. Passive Q-switching with GaAs or Bidoped GaAs saturable absorber in Tm: LuAG laser operating at $2 \mu \mathrm{m}$ wavelength. // Optics Express. 23, 12(2015), pp. 15469-15476. DOI: 10.1364/OE.23.015469
[3] Korenfeld, A.; Daniel, S.; Udi, B. A.; Eran, S.; Gilad, M.; Salman, N. High pulse energy passive Q-switching of a diode-pumped Tm: YLF laser by Cr: ZnSe. // Laser Physics Letters. 12, 4(2015). DOI: 10.1088/1612-2011/12/4/045804

[4] Raikkonen, E. T. Miniature passively Q-switched lasers and their application to nonlinear frequency conversion in microstructure optical fiber. // Faculty of Information and Natural Sciences, Helsinki University of Technology.

[5] Yongan, T.; Azad, S.; Granieri, S.; Markus, P. M. Optical switching in a resonant Fabry-Perot saturable absorber. // Journal of Optics A: Pure and Applied Optics. 1, 8(2006), pp. 9-17.

[6] Jin, C.; Diao, L.; Yang, B.; Zhaoyu, R.; Jintao, B. Wideband tunable graphene-based passively Q-switched Tm: YAP laser. // Laser Physics. 25, 4(2015). DOI: 10.1088/1054-660X/25/4/045802

[7] Zeng, X.; Sulmoni, L.; Lamy, J. M.; Stadelmann, T. S.; Grossmann, A.; Hoogerwerf, C.; Nicolas, G.; Boïko, D. L. Solitary pulse-on-demand production by optical injection locking of passively Q-switched InGaN diode laser near lasing threshold. // Applied Physics Letters, 106, 7(2015). DOI: $10.1063 / 1.4907638$

[8] Liu, J.; Wenjuan, H.; Xiaowen, C.; Qibiao, D.; Haohai, Y.; Huaijin, Z. Continuous-Wave and Passive Q-Switching Laser Performance of $\mathrm{Yb}$ : YCa O (BO) Crystal. IEEE // Journal of Selected Topics in Quantum Electronics. 21, 1(2015), pp. 348-355. DOI: 10.1109/JSTQE.2014.2336534

[9] Avrutin, E. A. Analysis of spontaneous emission and noise in Self-pulsing Laser Diodes. // IEEE proceedings, 1, 140(1993), pp. 1190-1198.

[10] Karkhanehchi, M. M.; Parandin, F. Calculation and simulation of passive Q-Switching Diode laser parameters. // Proceeding of the 6th WSEAS international conference on simulation, modeling and optimization, Lisbon, Portugal, 2006. pp. 95-104.

\section{Authors' addresses}

\section{Fariborz Parandin, PhD, Lecturer}

1) Department of Electrical Engineering, Eslam Abad Gharb Branch, Islamic Azad University, Eslam Abad Gharb,

Kermanshah, Iran

2) Department of Electronic Engineering, Faculty of Engineering, Razi University, Kermanshah, Iran

E-mail: fparandin@yahoo.com

Mohammad Mehdi Karkhanehchi, PhD, Assistant Professor Department of Electronic Engineering, Faculty of Engineering, Razi University, Kermanshah, Iran, P. O. Box: 67149-67346. E-mail: mkarkhanehchi@razi.ac.ir

Reza Hemmati, PhD, Assistant Professor Department of Electrical Engineering, Kermanshah University of Technology, Kermanshah, Iran, P. O. Box: 63766-67178.

E-mail: reza.hematti@gmail.com

\section{Naser Mahtabi, MSc, Lecturer}

Department of Electrical Engineering, Eslam Abad Gharb Branch, Islamic Azad University, Eslam Abad Gharb, Kermanshah, Iran E-mail: nasermahtabi@yahoo.com 